managers to reflect on their performance and by identifying and transmitting local examples of successful practice - act as small catalysts to the improvement of the performance and effectiveness of managers in the region.

\title{
References
}

Bögel G./ Edwards V./ Wax M. (1997): Hungary Since Communism, The Transformation of Business, Macmillan.

Celli P. (1997): L'illusione manageriale, Laterza.

Gill J. and Johnson P. (1991): Research Methods for Managers, Paul Chapman Publishing.

Linstead S. (1996): 'Understanding Management: Culture, Critique and Change', in Linstead S., Grafton Small R. and Jeffcutt P., (eds.) Understanding Management, Sage, pp.1133.

Maruyama M. (1993): 'Survival, Adaptive and Maladaptive Strategies and Pitfalls in Management Transfer: Lessons from Other Parts of the World and their Use in Management Reform in Central and Eastern Europe', in Maruyama M. (ed.), Management Reform in Eastern and Central Europe, Dartmouth, pp.163-73.

Ogger G. (1992): Nieten in Nadelstreifen, Droemer Knaur.

Pieper R. (ed.) (1989): Westliches Management - östliche Leitung, Walter de Gruyter.

Soulsby A. and Clark E. (1996): 'The Emergence of Post-Communist Management in The Czech Republic', Organization Studies, Vol.17/2, pp.227-47.

\section{Researching Management in Central and Eastern Europe: Re- searcher, Manager and Management Practice - Comment and Views}

\section{Danijel Pucko, University of Ljubljana, Slovenia}

When analysing research endeavours in the management field in Central and Eastern Europe in the transition, one has to define the meaning of management. My understanding of management is based on the definition that management is the process of organising and directing human and physical resources within an organisation to meet defined objectives (Collins Dictionary of Business, 1991). The key management roles include many, they extend from planning to control. Some more broader interpretation of management might open the space to analyse privatisation, SME sector development, and some other issues too. One can perceive management in a more narrow or in a broader sense. My comment and views will be based on the first more restricted meaning of management. 
It is hard to say if the breakdown of the communist regimes in Central and Eastern Europe increased the research endeavours in general in the region. It is no doubt that the interest for the research of the transitional phenomena expanded in the West. My belief is that the size of the research endeavours in the field of management has somehow even decreased in the transitional countries in the nineties. Two causes could be identified for such a move. The first is linked to the big fall in the GDP of the transitional countries. There are less financial resources for the research in general. The second cause might be seen in the expanded interest in the region for managerial knowledge and skills. Many universities and other human scientific resources have dedicated more of their time to teaching and training in the management field and less to research activities.

My impression is that the dominant share of the research done by the Westerners in the region has been directed to macroeconomic issues of the transition. Privatisation, foreign direct investments and the SME sector development have prevailed. On the micro level, case studies of individual companies attracted interests of the Western researchers the most. Foreign consulting companies have been very active in the field of case studies too. This impression one can get on the basis of papers submitted by Westerners on scientific conferences held in the region in the last years (Buckinghamshire 1995, Split 1995, Ljubljana 1996, Chemnitz 1997, Split 1997, Buckinghamshire 1998, Portorož 1998).

The transitional countries are confronted with the lack of managerial knowledge and skills. Nobody can deny it. This lack exists in a different extent in different transitional countries. The lack is the biggest in the financial management field because there were no capital markets, stock exchanges, securities, very weak investment banking, no real acquisitions, take-overs, etc. in the previous socialist systems. The lack is somehow not so terrible regarding the general management as well as functional management knowledge and skills. Still the overall quality level of management has too be upgraded essentially. Therefore there is a big need for the intense research in the management field as well as for training in all fields of management.

The position of managers in the CEE countries is certainly a challenging and valuable research topic. Who are the managers in the region? Which are their personal values and objectives? What are their professional and other capabilities? Is there some continuity or is there a clear discontinuity present regarding managing cadres in the transitional companies? All these and other issues are relevant for the research of managers in the transition. According to my insights both groups of managers are active in transitional countries. The first group consists of managers who already were on these positions in the previous socialist system. The second group consists of "new", mostly younger persons who took over managerial positions in the transition period. Most of the latter group holds university education, but are not very well equipped with management knowledge and skills. These two samples of managers still have different practicable 
experiences and use two different behaviour patterns. In spite of the stated differences a certain process of convergence in the managerial behaviour could be identified when one compares the behaviour of the managers in the Western Europe and of the managers in the CEE countries (Pučko, Lahovnik, 1998).

Besides the position of managers the most research interest in the management field was attracted by a few topics in the CEE countries in the nineties. Company restructuring and crisis management issues, business ethics and organisational culture, SMEs (founding and managing), human resource management issues and FDIs were the issues that dominated on the conferences in the region (See the above stated conferences). In the recent future, I assess, the priorities will be given to the topics like company governing systems, acquisitions, and strategic and other aspects of the integration into the EU (the latter will be important for the Central European countries). Of course there will be present a permanent research interest for the upgrading and improving of practically all management processes as well.

Historical and cultural factors have a strong influence on the practice of management (Lubatkin, Floyd, 1997). This fact contributes to the need for joint research of management phenomena in the region done by both insiders and outsiders. Western researchers may be understood in this context as outsiders. The researchers who live and work in the region may be perceived as insiders.

Historical and cultural factors are also important in developing relations between managers and researchers. I strongly believe that the participative way of doing research in management could be the most productive, but it is and will be in most cases nearly unachievable. It has been achieved in some case studies carried out by a foreign (less frequently domestic) consulting firms. Different professional educational and training programmes have offered a few opportunities for this kind of approach, too. I mean all those cases where the students in MBA and some other programmes have been acting managers. They have prepared many empirical research projects and papers that really mean some joint research work of managers and their trainers.

The prevailing research approach is most frequently one by which the researcher is in the role to explore, to discover what is going on and to identify significant characteristics and factors of ongoing management processes as well as their determinants. Managers show formally keen interest for the research findings and results. They are not ready to participate seriously in the research endeavours. My findings have been even that they are not very eager "to open cards to a researcher" fully. This attitude had been very much present in the period before the companies got the approval for their privatisation programmes. A fear that a researcher will get some information on the company that should be kept secret is still present among managers in the post privatisation period. One possible explanation for such behaviour could be a potential danger for the new revision of the company privatisation that still persists in some transitional countries. 
Let me finish my short comment by saying that I feel a need for many more international comparative research projects in the field of management. There have been some international comparative research projects carried out by mixed teams of Westerners and researchers from the region. Not enough. On the other hand there have been nearly no research projects carried out internationally by the researchers of the region alone. A few Phare projects are exemptions in this regards. They have provided basically a ground for such an approach. Governments and other funding agencies in CEE countries should stimulate much more this kind of research than it has been the case up to now.

\section{References:}

1 st International Conference on Enterprise in Transition, University of Split, Faculty of Economics, Split, October 4-6, 1995

50th Anniversary of the Faculty of Economics, International Conference, Collection of Abstracts, University of Ljubljana, Ljubljana, 1996

Collins Dictionary of Business, 1991

Enterprise in Transition, Proceedings of the Second International Conference On Enterprise in Transition, Daam International Vienna, Austria \& University of Split, Faculty of Economics, Croatia, Brela, May 22-24, 1997

Lubatkin M./ Floyd S.: In Search of a European Model of Strategic Management, European Management Journal, 1997, Vol. 15, No.6, p. 612-624

Management Executives in the East European Transformation Process, III. Chemnitzer Ost Forum, Technische Universitaet, Chemnitz-Zwickau, 5.-7. Marz 1997

Management Zwischen Krise und Erfolg, Internationales Wissenschaftliches Symposium, MER 98, Slowenien, Portorož, 11.-13. Mai 1998

Proceedings of the Conference on Central and Eastern Europe: 5 Years On, CREEB, The Business School, Buckingham College, Newland Park, UK, 20-21 June 1995

Proceedings of the Fourth Annual Conference on Convergence or Divergence: Aspirations and Reality in Central and Eastern Europe and Russia, CREEB, Buckinghamshire Business School, UK, 23-24 June 1998

Pucko D./ Lahovnik M.: Changes in Strategic Behaviour of Slovenian Small Businesses in the Transition Period - Convergence or Divergence, In: Proceedings of the Fourth Annual Conference on Convergence or Divergence: Aspirations and Reality in Central and Eastern Europe and Russia, CREEB, Buckinghamshire Business School, UK, 23-24 June 1998 